\title{
Seroprevalence and Spatial Distribution of Toxoplasmosis in Sheep and Goats in North-Eastern Region of Pakistan
}

\author{
Haroon Ahmed ${ }^{1,2}$, Ayesha Malik ${ }^{3}$, Muhammad Arshad ${ }^{3}$, Irfan Mustafa4, Mobushir Riaz Khan ${ }^{5}$, \\ Muhammad Sohail Afzal ${ }^{6}$, Shahzad Ali ${ }^{7}$, Muhammad Mobeen ${ }^{8}$, Sami Simsek ${ }^{2, *}$ \\ ${ }^{1}$ Department of Biosciences,COMSATS Institute of Information Technology (CIIT), Islamabad, Pakistan; ' 2 Department of Parasitology, Faculty of \\ Veterinary, University of Firat, 23119, Elazig, Turkey; '² Department of Zoology, University of Sargodha, Pakistan; 4 Department of Biology, \\ Government Postgraduate College Chishtian, Punjab, Pakistan; ${ }^{5}$ Department of Remote Sensing \& GIS, PMAS-University of Arid Agriculture, \\ Rawalpindi, Pakistan; ${ }^{6}$ Department of Chemistry, School of Science, UMT Lahore, Pakistan; ${ }^{7}$ Department of Wildlife and Ecology, University of \\ Veterinary and Animal Sciences, Lahore, Pakistan; ${ }^{8}$ Department of Earth Sciences, University of Sargodha, Pakistan
}

\begin{abstract}
Toxoplasmosis is a protozoan disease that is caused by Toxoplasma gondii in livestock and humans. Due to its medical and veterinary importance, it is essential to study the seroprevalence of $T$. gondii infection among humans and animals in various parts of the world. The major objective of this study was to determine the seroprevalence and spatial distribution of toxoplasmosis in small ruminants (sheep and goats) of north-eastern region, Pakistan. A total of 1,000 animals comprising of sheep $(n=470)$ and goats $(n=530)$ were examined for T. gondii infection by using ELISA. An epidemiological data was collected in the form of questionnaire. A surface has been generated by using method of interpolation in Arc GIS with the help of IDW (inverse distance weight). The results showed higher seroprevalence of $T$. gondii in goats $(42.8 \%)$ as compared to sheep (26.2\%). The seroprevalence was higher in females as compared to males in all examined ruminants. Similarly, there is a wide variation in the seroprevalence of $T$. gondii in different breeds of sheep and goats showing higher seroprevalence in Teddy (52.8\%) and Damani breed (34.5\%) of goat and sheep's, respectively. The geographical and spatial distribution of $T$. gondii shows that it is widely distributed in different parts of the north-eastern region of Pakistan. Our results suggest widespread environmental contamination with $T$. gondii oocysts. It suggests us that small ruminants could be a potentially important source of $T$. gondii infection if their infected meat is consumed undercooked.
\end{abstract}

Key words: Toxoplasma gondii, ELISA, seroprevalence, sheep, goat, spatial distribution, Pakistan

\section{INTRODUCTION}

Livestock production is a vital component of world's agriculture. Throughout the world, human populations greatly depend on domestic animals for many purposes, especially the meat production, milk, fat, other dairy products, eggs, and fibers like wool or cashmere as well as other purposes [1]. Out of total 79.61 million hectare (MH) geographical area, only $59.28 \mathrm{MH}$ is the reported area of Pakistan; 62.18\% of the total geographical area of Pakistan is the rangeland which is $49.5 \mathrm{MH}$, and most of the small ruminants and camels are supported by this area [2]. There are many epidemics that cause high mortality and morbidity in livestock sector of Pakistan [3]. The economic losses

\footnotetext{
- Received 20 April 2016, revised 9 June 2016, accepted 15 June 2016.

*Corresponding author (ssimsek@firat.edu.tr)

(C) 2016, Korean Society for Parasitology and Tropical Medicine

This is an Open Access article distributed under the terms of the Creative Commons

Attribution Non-Commercial License (http://creativecommons.org/licenses/by-nc/4.0) which permits unrestricted non-commercial use, distribution, and reproduction in any

medium, provided the original work is properly cited.
}

due to these diseases have been estimated to be 79 billion Pakistani rupees which are almost equal to 1 billion US dollars [4]. Toxoplasmosis is one of the most common parasitic diseases in animals and humans that placed the third on the top of world spread. Globally, 30-65\% people are infected with toxoplasmosis [5]. It has economic significance to both veterinary and human medicine because Toxoplasma gondii is responsible for birth defects and abortions in intermediate hosts $[5,6]$.

Toxoplasmosis is a widespread zoonosis that is caused by intracellular parasite, T. gondii [7]. Toxoplasmosis ranks high which lead to death in patients with AIDS. In USA, 10\% of AIDS patients and up to $30 \%$ in Europe are estimated to die from toxoplasmosis [6]. This parasite is transmitted by contaminated meat (sheep, goat, and pig), milk (sheep, goat, and cattle), and chicken eggs [8]. Milk of these animals contains the tachyzoite stage of the parasite [5]. The use of goat milk is elevated in children with allergy to milk of cattle in many rural areas of Pakistan [9]. Humans can accidentally ingest oocysts that cats have excreted in their stool or it can be transmitted to 
humans by unwashed vegetables or fruits or contaminated water [7].

The prevalence of T. gondii in Pakistan has increased due to lack of modern farming and open-air markets because of the presence of wandering cats around markets [10]. There are few reports on the prevalence of toxoplasmosis in small ruminants in different parts of Punjab, Pakistan. The seroprevalence in sheep's of southern Punjab was 19.9\% [11] and in Pothowar region, it was $18.2 \%$ and $14.3 \%$ in sheep and goats, respectively [12], while in Rahim Yar Khan region, it was $11.2 \%$ and $25.4 \%$ in sheep and goats, respectively [13].

The aim of the present study was to determine the serop revalence and spatial distribution of toxoplasmosis in small ruminants (sheep and goats) of north-eastern region of Punjab province, Pakistan.

\section{MATERIALS AND METHODS}

\section{Study area}

A seroepidemiological survey was conducted in different agro-ecological zones of Punjab province, Pakistan which comprises of Bhalwal, Kotmomin, Sahiwal, Shahpur, Silanwali, and Sargodha districts (Fig. 1).

\section{Topography}

Sargodha is located in the northeast region of Pakistan. Geographical coordinates of Sargodha is $32.1667^{\circ} \mathrm{N}, 72.5000^{\circ} \mathrm{E}$. It mainly comprises flat, fertile plains, although there are a few small hills on the Sargodha-Faisalabad Road. The River Jhelum flows on the western and northern sides, and the River Chenab lies on the eastern side of the city. The city has a climate of extreme hot and cold. The maximum temperature reaches $50^{\circ} \mathrm{C}$ $\left(122^{\circ} \mathrm{F}\right)$ in summer while in winter the minimum temperature recorded is as low as freezing point. Sargodha is largely an agricultural and industrial city. The high temperature during summer creates much heat and heat affects the health of people living in this area. The humidity reaches up to $69 \%$ throughout the year. The monthly amount of precipitation has been recorded at around $82 \mathrm{~mm}$, that's 3 inches.The vast fields in the city have allowed the farmers to develop a range of

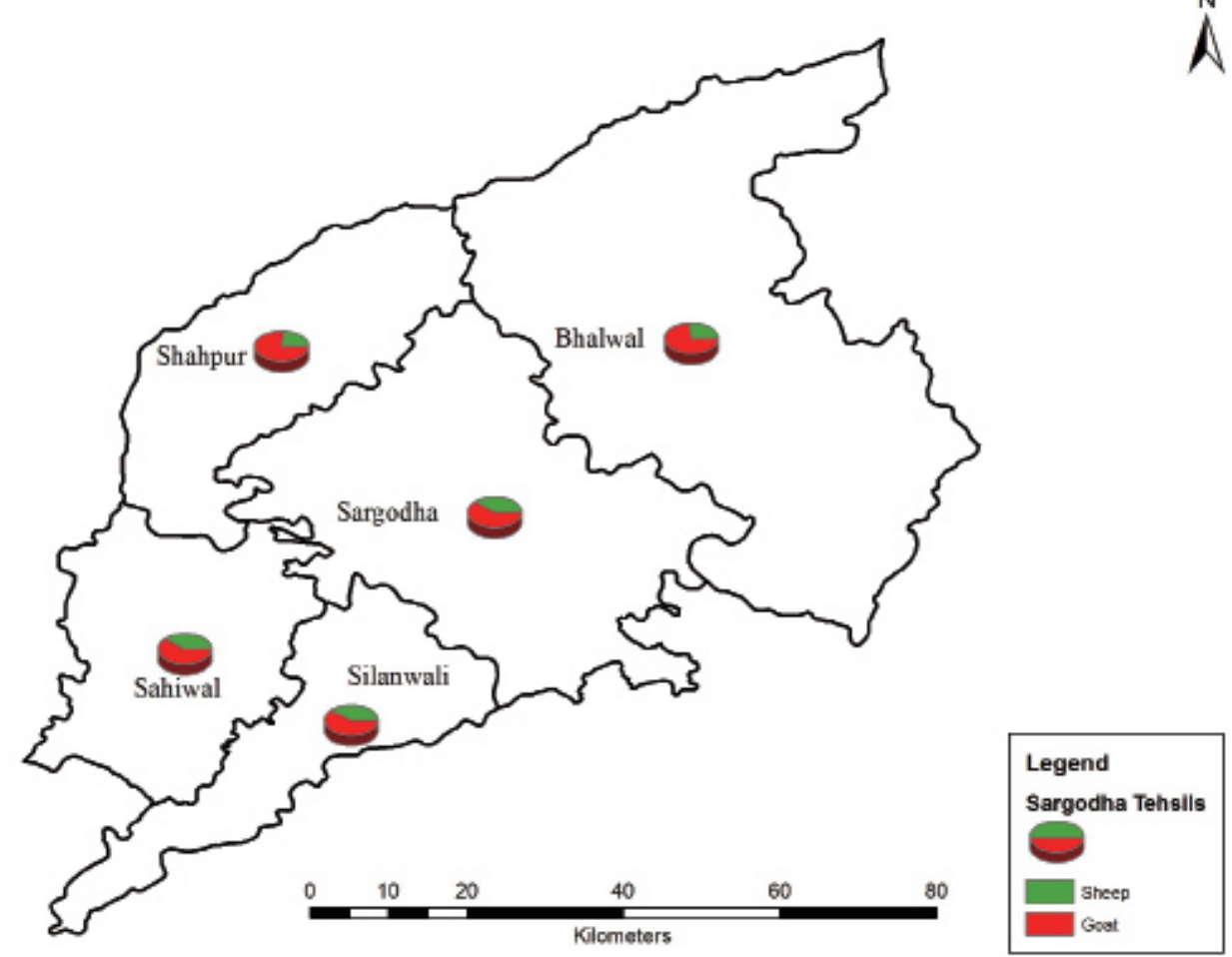

Fig. 1. The sampling sites of goats and sheep in Bhalwal, Kotmomin, Sahiwal, Shahpur, Silanwali, and Sargodha districts. (1) Bhalwal Tehsil is located in the eastern part of Punjab province of Pakistan. (2) Shahpur Tehsil lies on the Jhelum River. (3) Kot Momin is situated almost $40 \mathrm{~km}$ away from Sargodha tehsil. (4) Sahiwal tehsil is a subdivision (Tehsil) of Sargodha district. (5) Sargodha Tehsil is an administrative subdivision of Sargodha district. 
crops and animal breeding programs. The main livestock for the city include goats, sheep, buffaloes, and cattle.

\section{Sample collection}

One thousand blood samples comprising of goats $(n=530)$ and sheep $(\mathrm{n}=470)$ were collected randomly from different tehsils (Sargodha, Kotmomin, Bhalwal, Shahpur, Sahiwal, and Silanwali) from January 2013 to December 2013 (Figs. 1, 2). Blood samples ( $5 \mathrm{ml}$ ) were taken from jugular veins of sheep and goats. The sera was separated by centrifugation and stored at $-20^{\circ} \mathrm{C}$ until used. The study was approved from the committee (no. 125).

\section{Serological test (ELISA)}

Serum specimens were tested by ELISA to detect anti-Toxoplasma IgG and IgM antibodies using a commercial ELISA Kit (ID Screen Toxoplasmosis Indirect ${ }^{\circledR}$, ID-VET Company, Montpellier, France) according to manufacturer's instructions. The results were also interpreted according to the instructions of the manufacturer.

\section{Epidemiological factors}

The seroprevalence was determined on the basis of epidem iological factors. The informations (tehsils, age, sex, breed, and species of livestock) were collected in the form of questionnaire.

\section{Statistical analysis}

The statistical analyses were done by using SPSS 18 Software for Windows (chi-square test and $t$-test).

\section{RESULTS}

This is the first epidemiological study on T. gondii infection in sheep from north-eastern region as well as in goats from this region of Pakistan by using serological test. Out of 1,000 examined animals, the seroprevalence of $T$. gondii was higher in goats (42.8\%) than sheep (26.2\%). While, based on different breed of goats, it was Teddy (52.8\%), Beetal (48.5\%), Kamori $(47.5 \%)$, and Phari $(18.5 \%)$. Whereas, the seroprevalence based on different breeds of sheep was Dmani (34.5\%), Kajili (26.3\%), and Desi (20.3\%) (Table 1).

The impact of different risk factors on the geographical distribution of T. gondii was determined in the present study. Females were more commonly infected as compared to males in both the ruminant spp. Risk factors for infection with T. gondii in sheep having older age were more infected thus predicting

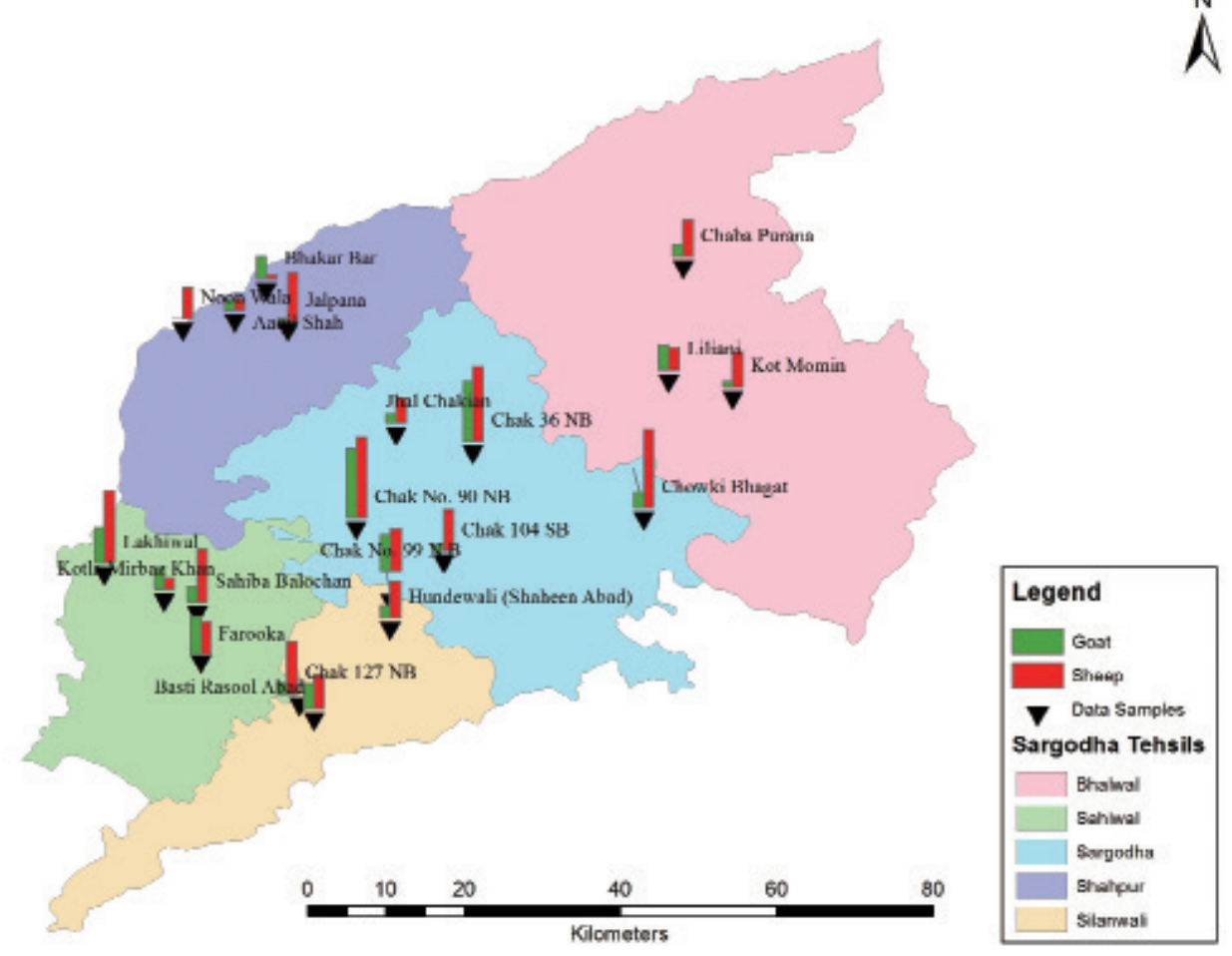

Fig. 2. Showing the proportion of different sampling sites with goats and sheep of study area. 
Table 1. The effect of species, sex, and breed on seroprevalence of toxoplasmosis

\begin{tabular}{|c|c|c|c|c|c|}
\hline Host & Sex/Breed & Examined (n) & Infected (n) & Seroprevalence (\%) & Statistical analysis; chi-square $\left(\chi^{2}\right)$ \\
\hline Goat & $\begin{array}{l}\text { Male } \\
\text { Female } \\
\text { Total }\end{array}$ & $\begin{array}{l}150 \\
380 \\
530\end{array}$ & $\begin{array}{r}35 \\
192 \\
227\end{array}$ & $\begin{array}{l}23.3 \\
50.5 \\
42.8\end{array}$ & 0.001 \\
\hline Sheep & $\begin{array}{l}\text { Male } \\
\text { Female } \\
\text { Total }\end{array}$ & $\begin{array}{r}72 \\
398 \\
470\end{array}$ & $\begin{array}{r}16 \\
107 \\
123\end{array}$ & $\begin{array}{l}22.2 \\
26.9 \\
26.2\end{array}$ & 0.003 \\
\hline Goat & $\begin{array}{l}\text { Beetal } \\
\text { Teddy } \\
\text { Kamori } \\
\text { Pahari } \\
\text { Total }\end{array}$ & $\begin{array}{l}167 \\
127 \\
121 \\
115 \\
530\end{array}$ & $\begin{array}{r}81 \\
67 \\
58 \\
21 \\
227\end{array}$ & $\begin{array}{l}48.5 \\
52.8 \\
48.0 \\
18.3 \\
42.8\end{array}$ & 0.021 \\
\hline Sheep & $\begin{array}{l}\text { Kajil } \\
\text { Desi } \\
\text { Damani } \\
\text { Total }\end{array}$ & $\begin{array}{l}180 \\
177 \\
113 \\
470\end{array}$ & $\begin{array}{r}48 \\
36 \\
39 \\
123\end{array}$ & $\begin{array}{l}26.7 \\
20.3 \\
34.5 \\
26.2\end{array}$ & 0.001 \\
\hline
\end{tabular}

Table 2. The effect of district and age on seroprevalence of toxoplasmosis

\begin{tabular}{|c|c|c|c|c|c|}
\hline Host & Factors & No. examined & No. infected & Seroprevalence (\%) & Statistical analysis; chi-square $\left(\chi^{2}\right)$ \\
\hline Goat & $\begin{array}{l}\text { Bhalwal } \\
\text { Sahiwal } \\
\text { Shahpur } \\
\text { Silanwali } \\
\text { Sargodha } \\
\text { Total }\end{array}$ & $\begin{array}{r}86 \\
105 \\
74 \\
148 \\
117 \\
530\end{array}$ & $\begin{array}{r}38 \\
46 \\
19 \\
53 \\
71 \\
227\end{array}$ & $\begin{array}{l}44.2 \\
43.8 \\
25.7 \\
35.8 \\
60.7 \\
42.8\end{array}$ & 0.001 \\
\hline Sheep & $\begin{array}{l}\text { Bhalwal } \\
\text { Sahiwal } \\
\text { Shahpur } \\
\text { Silanwali } \\
\text { Sargodha } \\
\text { Total }\end{array}$ & $\begin{array}{r}113 \\
70 \\
90 \\
137 \\
60 \\
470\end{array}$ & $\begin{array}{r}18 \\
23 \\
7 \\
46 \\
29 \\
123\end{array}$ & $\begin{array}{r}15.9 \\
32.9 \\
7.8 \\
33.6 \\
48.3 \\
26.2 \\
\end{array}$ & 0.002 \\
\hline Goat & $\begin{array}{l}\leq 1.5 \mathrm{yr} \\
1.5-3 \mathrm{yr} \\
\geq 3 \mathrm{yr} \\
\text { Total }\end{array}$ & $\begin{array}{l}193 \\
122 \\
215 \\
530\end{array}$ & $\begin{array}{r}71 \\
49 \\
107 \\
227\end{array}$ & $\begin{array}{l}36.8 \\
40.2 \\
49.8 \\
42.8\end{array}$ & 0.003 \\
\hline Sheep & $\begin{array}{l}\leq 1.5 \mathrm{yr} \\
1.5-3 \mathrm{yr} \\
\geq 3 \mathrm{yr} \\
\text { Total }\end{array}$ & $\begin{array}{l}206 \\
105 \\
159 \\
470\end{array}$ & $\begin{array}{r}27 \\
33 \\
63 \\
123\end{array}$ & $\begin{array}{l}13.1 \\
31.4 \\
39.6 \\
26.2\end{array}$ & 0.004 \\
\hline
\end{tabular}

that animals have more chances of infection in old age. The statistical analysis showed significant differences in different age groups of sheep and goats (Table 2).

The results showed that there is a significant variation $(P<0.05)$ in the prevalence and geographical distribution of toxoplasmosis in goats and sheep of rural areas in different districts (Fig. 2). The rate of infection in sheep of district Sargodha (48.3\%) was higher followed by Silawali (33.6\%), Sahiwal (32.9\%), Bhalwal (15.9\%), and Shahpur (7.8\%), while goats of district Sargodha $(60.7 \%)$ had a higher seroprevalence followed by Sahiwal (43.8\%), Bhalwal (44.2\%), Silawali (35.8\%), and Shahpur (25.7\%). The village-wise prevalence was given in Table 3.
There is a wide variation in geographical and spatial dist ribution of toxoplasmosis in rural areas of north-eastern region of Pakistan. There are different risk areas of toxoplasmosis in rural areas/villages of the north-eastern region of Pakistan.

A surface has been generated by using the method of interpolation in Arc GIS with the help of IDW (inverse distance weight). The following map showed the spatial trends among the goats in the study area. The north-western patch of the map, shown in red color, expressed the percentage of seropr evalence of toxoplasmosis from 9-19. The central portion of the map showed the maximum percentage of seroprevalence ranges from 47-57. The south-western extreme of the study area showed the percentage of seroprevalence from 28-38; this 
Table 3. The effect of herds in different districts on seroprevalence of toxoplasmosis

\begin{tabular}{|c|c|c|c|c|c|c|c|c|c|c|}
\hline Hosts & Districts & Village Name & Latitude & Longitude & $\begin{array}{c}\text { No. } \\
\text { examined }\end{array}$ & $\begin{array}{c}\text { No. } \\
\text { infected }\end{array}$ & $\begin{array}{c}\text { Seroprevalence } \\
(\%)\end{array}$ & $\begin{array}{l}\text { No. } \\
\text { examined }\end{array}$ & $\begin{array}{c}\text { No. } \\
\text { infected }\end{array}$ & $\begin{array}{c}\text { Seroprevalence } \\
(\%)\end{array}$ \\
\hline \multirow[t]{20}{*}{ Sheep } & \multirow[t]{4}{*}{ Bhalwal } & ChabaPurana & 32.3382 & 72.9711 & 30 & 4 & 13.3 & \multirow{4}{*}{113} & \multirow{4}{*}{18} & \multirow{4}{*}{15.9} \\
\hline & & Liliani & 32.208 & 72.955 & 25 & 7 & 28.0 & & & \\
\hline & & KotMomin & 32.1883 & 73.0286 & 30 & 2 & 6.6 & & & \\
\hline & & Chowki Bhagat & 32.049 & 72.9261 & 28 & 5 & 17.9 & & & \\
\hline & \multirow[t]{4}{*}{ Sahiwal } & Farooka & 31.8847 & 72.417 & 14 & 6 & 42.9 & \multirow{4}{*}{70} & \multirow{4}{*}{23} & \multirow{4}{*}{32.9} \\
\hline & & Sahiba Balochan & 31.9403 & 72.4125 & 17 & 3 & 17.6 & & & \\
\hline & & Kotla Mirbaz Khan & 31.955 & 72.3748 & 21 & 6 & 28.6 & & & \\
\hline & & Lakhiwal & 31.9858 & 72.306 & 18 & 8 & 44.4 & & & \\
\hline & \multirow[t]{4}{*}{ Shahpur } & Aaqil Shah & 32.2762 & 72.4558 & 23 & 3 & 13.0 & \multirow{4}{*}{90} & \multirow{4}{*}{7} & \multirow{4}{*}{7.8} \\
\hline & & Jalpana & 32.2617 & 72.5198 & 26 & 1 & 3.8 & & & \\
\hline & & Bhakar Bar & 32.3122 & 72.4924 & 20 & 5 & 25.0 & & & \\
\hline & & Noon Wala & 32.2669 & 72.3961 & 21 & 0 & 0.0 & & & \\
\hline & \multirow[t]{4}{*}{ Silanwali } & Chak No. 99 N.B & 31.9546 & 72.6351 & 34 & 16 & 47.1 & \multirow{4}{*}{137} & \multirow{4}{*}{46} & \multirow{4}{*}{33.6} \\
\hline & & Hundewali (Shaheen Abad) & 31.922 & 72.6344 & 30 & 6 & 20.0 & & & \\
\hline & & Chak $127 \mathrm{NB}$ & 31.835 & 72.5302 & 36 & 14 & 38.9 & & & \\
\hline & & Basti Rasool Abad & 31.8185 & 72.5468 & 37 & 10 & 27.0 & & & \\
\hline & \multirow[t]{4}{*}{ Sargodha } & Chak 104 SB & 31.9995 & 72.6961 & 21 & 4 & 19.0 & \multirow{4}{*}{60} & \multirow{4}{*}{29} & \multirow{4}{*}{48.3} \\
\hline & & Chak 36 NB & 32.1261 & 72.7297 & 12 & 8 & 66.7 & & & \\
\hline & & Jhal Chakian & 32.1476 & 72.6417 & 10 & 4 & 40.0 & & & \\
\hline & & Chak No. 90 NB & 32.038 & 72.596 & 17 & 13 & 76.5 & & & \\
\hline \multirow[t]{20}{*}{ Goats } & \multirow[t]{4}{*}{ Bhalwal } & Phularwan & 32.3535 & 73.0141 & 22 & 9 & 40.9 & & & \\
\hline & & Deowal & 32.2151 & 72.9093 & 20 & 5 & 25.0 & & & \\
\hline & & Chak 11 SB & 32.159 & 72.9953 & 28 & 11 & 39.3 & 86 & 38 & 44.2 \\
\hline & & Mangowal & 32.2151 & 72.8155 & 15 & 13 & 86.7 & & & \\
\hline & Sahiwal & AzmatWala & 31.8946 & 72.4045 & 25 & 9 & 36.0 & & & \\
\hline & & Fateh Wala & 31.9254 & 72.4356 & 29 & 17 & 58.6 & & & \\
\hline & & Tibba & 31.9606 & 72.3929 & 31 & 4 & 12.9 & 105 & 46 & 43.8 \\
\hline & & Deenpur & 31.9683 & 72.2845 & 20 & 16 & 80.0 & & & \\
\hline & Shahpur & Shahpur Sadar & 32.2673 & 72.4762 & 16 & 2 & 12.5 & & & \\
\hline & & Jalpana & 32.2667 & 72.517 & 13 & 7 & 53.8 & & & \\
\hline & & Rehmam Abad & 32.3116 & 72.5332 & 19 & 1 & 5.3 & $/ 4$ & 19 & 25.1 \\
\hline & & Ichhar & 32.2411 & 72.4218 & 26 & 9 & 34.6 & & & \\
\hline & Silanwali & Chak No. 117 N.B & 31.9358 & 72.6485 & 34 & 16 & 47.1 & & & \\
\hline & & Chak No. 118 SB & 31.9245 & 72.6469 & 37 & 3 & 8.1 & & & \\
\hline & & Chak 126 NB & 31.8483 & 72.5362 & 31 & 18 & 58.1 & 148 & 53 & 35.8 \\
\hline & & Islam Nagar & 31.8208 & 72.5445 & 46 & 16 & 34.8 & & & \\
\hline & Sargodha & Awan Abad & 32.0011 & 72.719 & 24 & 11 & 45.8 & & & \\
\hline & & Chak 33 NB & 32.1237 & 72.7504 & 23 & 19 & 82.6 & & & \\
\hline & & LoddyWala & 32.1433 & 72.6611 & 33 & 09 & 27.3 & 117 & 71 & 60.7 \\
\hline & & Chak No. 95 NB & 32.0491 & 72.6026 & 37 & 33 & 89.0 & & & \\
\hline
\end{tabular}

value extended inside the districts up to its central tehsil Sargodha but there was discontinuous appearance of higher seroprevalence shown in brown patch ranging from 38-47 (Fig. 3). Similarly, the surface for sheep has been generated by using the method of interpolation in Arc GIS with the help of IDW. The given map shows the spatial trends among the sheep in the study area (Fig. 4).

The present seroepidemiological survey was based on field samples. It reflected the importance of studies on Toxoplasma on regional basis from ruminant spp. in Pakistan.

\section{DISCUSSION}

Toxoplasmosis is a cosmopolitan zoonotic infection caused by a coccidian protozoan T. gondii, which affects a wide range of hosts, including humans, mammals, and birds. It is one of the leading cause of serious economic losses and caprine abortion in sheep and goat industry on worldwide basis [14]. 


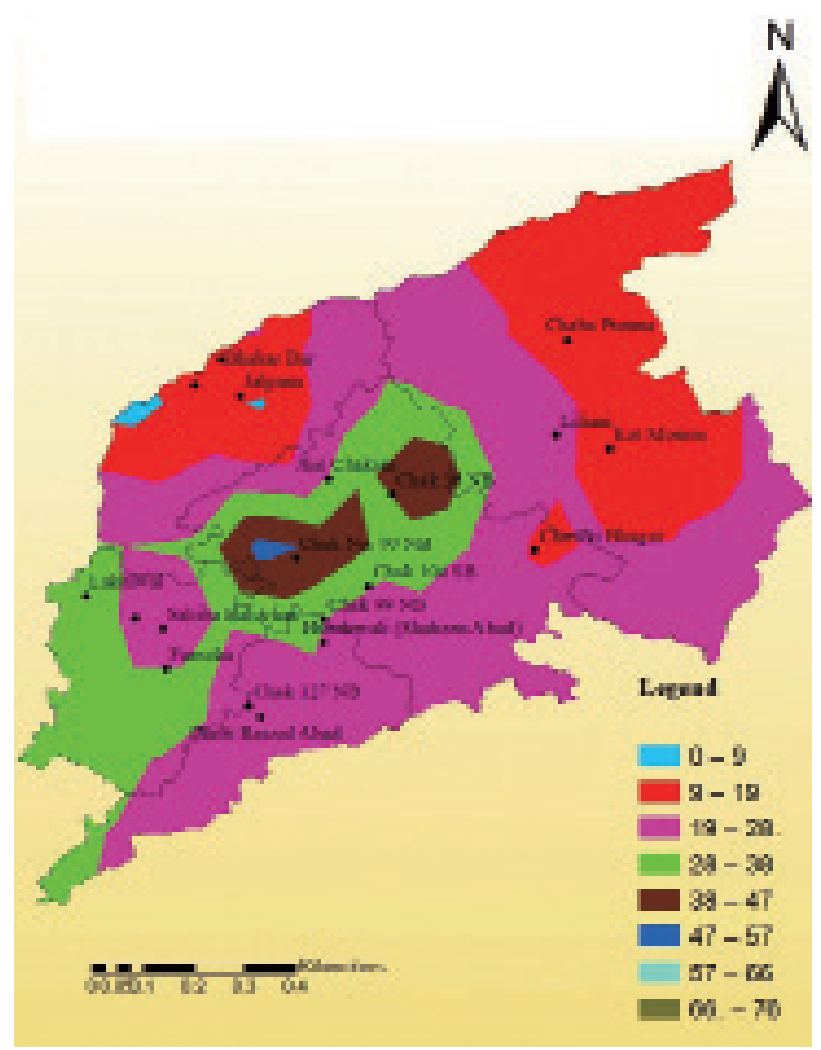

Fig. 3. Spatial trends of surfaces for the seroprevalence of toxoplasmosis in goats of urban areas.

The results of the present study showed that toxoplasmosis is more prevalent in goats than in sheep in north-eastern region of Pakistan. Our findings are consistent with that of Nisar et al. [12] who reported the higher seroprevalence of T. gondii in goats as compared to sheep in northern Punjab (Pakistan). Similar findings were reported by Ahmed et al. [15] and Ramzan et al. [9] that goats are more susceptible to toxoplasmosis as compared to sheep due to their higher activity and movement. It might increase the probability of contact with contaminated sources. These agreements may be attributed to grazing patterns where many sheep flocks grazed daily while goat flocks examined in this survey were housed. Therefore, the possibility of contact with contaminated food and pastures during grazing season was high in sheep flocks. There is a wider variation of distribution of Toxoplasma within Pakistan and across the world. The results showed that toxoplasmosis is widely distributed in sheep and goats of Sargodha, Sahiwal, Bhalwal, Silanwali, and Shaahpur districts. Similar findings were reported from southern parts of the country [9-11], NWFP [16], and in Iran, India, and China [17-19]. This significant variation in the

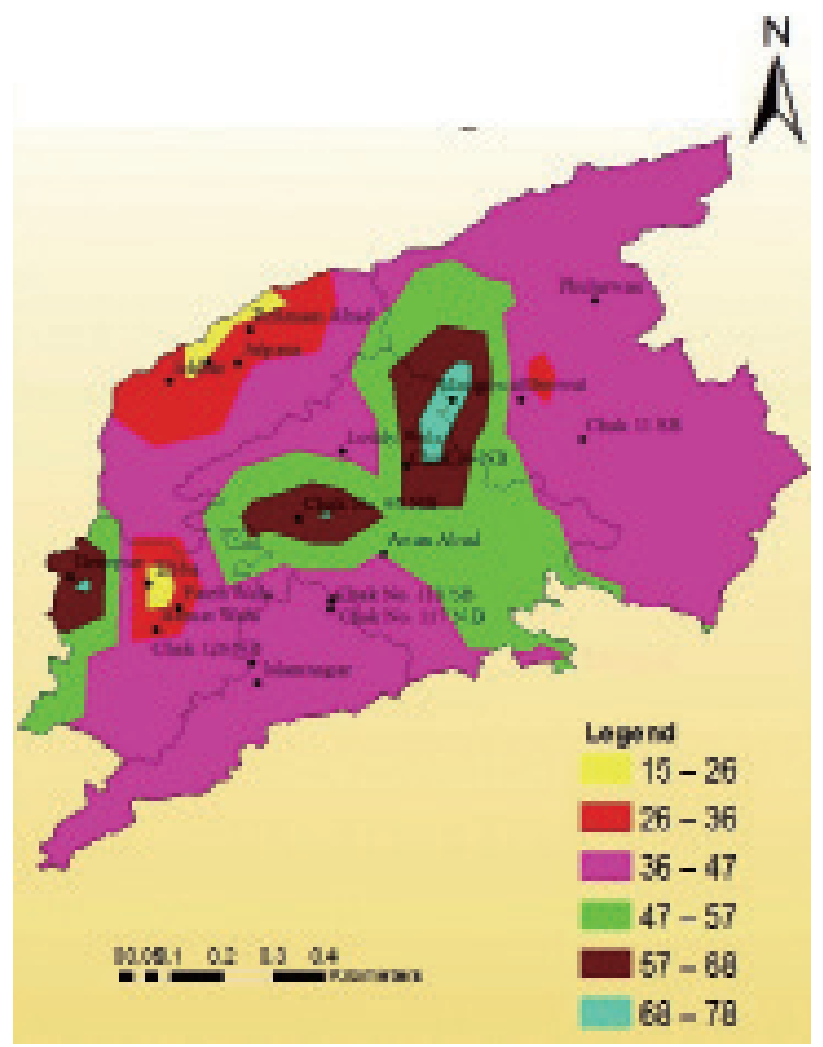

Fig. 4. Spatial trends of surfaces for the seroprevalence of toxoplasmosis in sheep of urban areas.

seroprevalence of toxoplasmosis in different areas is due to difference in the climate, hygienic conditions, farm managements, sample size, and serodiagnostic technique [19].

Toxoplasmosis is a zoonotic disease transmitted by direct or indirect contact with infected animals, soiled pasture and corrals, ingesting infected milk, and with semen from male to female animals [20,21]. The overall estimation of seroprevalence of $T$. gondii in Nile Delta regions was generally higher than Brucella melitensis. This may be attributed to periodical examination of small ruminants by the Veterinary Service Agency to T. gondii infection and slaughtering the infected animals. These screening procedures reduce the spread of toxoplasmosis among small ruminants compared to toxoplasmosis. Toxoplasmosis is endemic at high levels among the large ruminant population of the studied village in the Nile Delta region of Egypt, where the main risk factor for cattle and buffalo seropositive status is the presence of sheep or goats in the same household [22].

The results showed that Teddy (52.8\%) breed as compared to Beetal (48.5\%), Kamori (47.5\%), and Phari (18.5\%) breeds 
of goats. The results also showed higher seroprevalence in Teddy as compared to other breed which might be due to poor immune system and management. Similar observations were reported by Ahmad et al. [12] in Jattal, Beetal, and teddy breeds of goats. Whereas, seroprevalence based on different breeds of sheep was Dmani (34.5\%), Kajili (26.3\%), and Desi (20.3\%). The results showed higher seroprevalence in Dmani breed as compared to other breed might be due to poor management. Similar observations were reported by Ahmad et al. [12] in Salt, Afghani, and Awasi breeds of sheep.

The results showed that female animals were more infected as compared to males in both the ruminant species. It has been reported that female animals are more susceptible to toxoplasmosis than males in Pakistan [16].

Risk factors for infection with $T$. gondii in sheep having older age were more infected as compared to young animals thus predicting that animals have more chances of infection at older age. Similar observations were reported by Shah et al. [16]. Increase in the prevalence of the disease in older animals is due to exposure of animals to the risk factors for a longer period of time than younger ones. Similar findings in sheep and goats were reported by Lashari and Tasawar [11] and Tasawar et al. [10]. Our results were in contrary as reported by Ramzan et al. [9]. So, it is concluded from the present study that the seroprevalence of $T$. gondii infection in goats slaughtered for human consumption was high as compared to goats in north-east region of Pakistan. The study highlighted the potential public health importance of meat of sheep and goats as source of infection for humans. There should be some eradication strategies, and management practices should be implanted to reduce the prevalence rate in other agro-ecological zones of Pakistan.

\section{AUTHORS CONTRIBUTIONS}

HA and AM contributed equally in this study. IM designed the study, MA supervised the study, MRK developed the map, MM interpreted the maps, SA and MSF wrote the discussion section. SS critically reviewed and improved the quality of final manuscript.

\section{CONFLICT OF INTEREST}

The authors fully declare any financial or other potential conflict of interest.

\section{REFERENCES}

1. Ulvevadet B, Hausner VH. Incentives and regulations to reconcile conservation and development: thirty years of governance of the semi pastoral ecosystem in Finnmark, Norway. J Environ Mana gement 2011; 92: 2794-2802.

2. Sarwar M, Khan MA, Iqbal Z. Feed resources for livestock in Pakistan. Int J Agri Biol 2002; 1: 186-192.

3. Iqbal M, Ahmad M. An assessment of livestock production potential in Pakistan: implications for livestock sector policy. Pak Dev Res 2002; 38: 615-628.

4. Nazir F, Khan MA. Trends in milk production through community participation. The National Publications. 2009, p 1.

5. Tenter AM, Heckeroth AR, Weiss LM. Toxoplasma gondii from animals to humans. Int J Parasitol 2000; 30: 1217-1258.

6. Hill D, Dubey JP. Toxoplasma gondii: transmission, diagnosis and prevention. Clin Microbiol Infect Dis 2002; 8: 634-640.

7. Pavlovic I, Ivanovic S. Toxoplasmosis of goats and its role and importance in pathology of goat production. Biotech Anim Husband 2005; 21: 123-126.

8. Uttah E, Ogban E, Okonofua C. Toxoplasmosis: a global infection, so widespread, so neglected. Int J Sci Res Publication 2013; 3: $1-6$.

9. Ramzan M, Akhtar M, Hussain I, Muhammad F, Hiszczynska-Sawickaa E, Haq AU, Mahmood MS. Seroprevalence of Toxoplasma gondii in sheep and goats in the area of Rahim Yar Khan (Punjab). Trop Anim Health Prod 2009; 41: 1225-1229.

10. Tasawar Z, Lashari MH, Hanif M, Hayat CS. Seroprevalence of Toxoplasma gondii in domestic goats in Multan, Punjab, Pakistan. Pak J Sci 2011; 9: 24-27.

11. Lashari MH, Tasawar, Z. Seroprevalence of toxoplasmosis in sheep in Southern Punjab, Pakistan. Pak Vet J 2010; 30: 91-94.

12. Ahmad N, Iqbal, Z, Mukhtar M, Mushtaq M, Khan KM, Qayyum M. Seroprevalence and associated risk factors of toxoplasmosis in sheep and goats in Pothwar region, Northern Punjab, Pakistan. Pak J Zool 2015; 1: 161-167.

13. Ramzan M, Akhtar M, Muhammad F, Hussain I, HiszczyńskaSawicka E, Haq AU, Mahmood MS, Hafeez MA. Seroprevalence of Toxoplasma gondii in sheep and goats in Rahim Yar Khan (Punjab), Pakistan. J Trop Anim Health Prod 2009; 4: 12251229.

14. Buxton D, Maley SW, Wright SE, Rodger S, Bartley P, Innes EA. Toxoplasma gondii and ovine toxoplasmosis: new aspects of an old story. Vet Parasitol 2007; 149: 25-28.

15. Ahmed YF, Sokkar SM, Desouky HM, Soror AH. Abortion due to toxoplasmosis in small ruminants. Global Veterinaria J 2008; 6: 337-342.

16. Shah M, Zahid M, Asmat P, Alam A, Sthanadar A. Seroprevalence of Toxoplasma gondii in goats and sheep of district Mardan, Pakistan. Int J Biosci 2013; 7: 90-97.

17. Ghorbani M. Animal toxoplasmosis in Iran. J Trop Med Hyg 1983; 86: 73-80.

18. Sharma S, Sandhu KS, Bal MS, Kumar H, Verma S, Dubey JP. Se- 
rological survey of antibodies to Toxoplasma gondii in sheep, cattle and buffaloes in Punjab, India. J Parasitol 2008; 94: 11741175.

19. Zhao GH, Zhang MT, Lei LH, Shang CC, Cao DY, Tian TT, Li J, Xu JY, Yao YL, Chen DK, Zhu XQ. Seroprevalence of Toxoplasma gondii infection in dairy goats in Shaanxi Province, Northwestern China. Parasit Vectors 2011; 4: 47-51.

20. Renukaradhya GJ, Isloor S, Rajasekha, M. Epidemiology, zoonotic aspects, vaccination and control/eradication of brucellosis in In- dia. J Vet Microbiol 2002; 90: 183-195.

21. Al-Majali AM. Seroepidemiology of caprine brucellosis in Jordan. Small Rum Res 2005; 58: 13-18.

22. Hannah RH, Mahmoud ME, Yamen MH, Wae, FE, Ahmed AT, Javier G. Brucella spp. infection in large ruminants in an endemic area of Egypt: cross-sectional study investigating seroprevalence, risk factors and livestock owner's knowledge, attitudes and practices (KAPs). J BMC Public Health 2011; 1: 11, 341. 